\title{
Rural Farmers' Perception and Use of Soil Erosion Control Measures in South Africa: the Case of Upper and Lower Areas of Didimana
}

\author{
Ighodaro Ikponmwosa David $^{1 *}$ and Lewu Bayo Francis ${ }^{1}$
}

\begin{abstract}
This study assesses farmers' perception and use of soil erosion control methods in South Africa, using the Upper and Lower Areas of Didimana, Eastern Cape as a case study. Through a survey research, data were collected from 60 farmers, through the random data collection process, which formed the basis of discussion and conclusion. According to findings, though farmers' perception on soil erosion impact indicated a severe situation (53.3\%), an interesting proportion (42\%) of farmers was found not using extension advises and/or recommendations for soil erosion control in their area. While $37 \%$ use extension advises arbitrarily, only $21 \%$ use them as recommended. As such, the impact of soil erosion in the study area is on the rise. The recommendation therefore is that there is an urgent need to raise the level of information and engagement, as well as discourage rural-urban drift of youth in the area.
\end{abstract}

Key words - Rural farmers, rural farmers' perception, soil erosion, soil erosion control methods, Upper and Lower Areas of Didimana

\section{INTRODUCTION}

Two-thirds of the world's poor reside in sub-Saharan Africa, most of which are in rural areas [1], whose livelihood comes from agriculture [2]. Smallholder/rural agriculture is said to be responsible for up to $80 \%$ of the food supply needs in Asian and sub-Saharan African countries [3]. In fact, the case is even worse in Ethiopia, where $85 \%$ of her population lives in the rural areas, obtaining livelihoods from agriculture [4]. According to Masiwa [5], there are almost two million small-scale or household farmers (smallholder farmers) in South Africa; mostly residing in rural areas, and isolated from key markets and services essential for growth.

This paper was submitted on the $13^{\text {th }}$ of July, 2020; I.D. Ighodaro is a Postdoctoral Research Fellow, and F.B. Lewu is the HOD and Professor of Soil Science and Botany (with specialization in plant genetic conservation and propagation), both from the ${ }^{1}$ Department of Agriculture, Faculty of Applied Sciences, Cape Peninsula University of Technology, Wellington Campus, South Africa
Agriculture therefore for the rural people or less developed areas, especially for sub-Saharan Africa, remains a major growth factor. It is referred to by Linh et al. [6] as one of the crucial economic sectors of all economies, particularly in developing countries. Osabohien et al. [7] say that the sector contributes immensely to the general growth of developing economies of the world. Jayne et al. [8] posit, that smallholder-led development strategy would be the avenue to achieve the required economic transformation expected, and for general poverty alleviation. Concurring, Hossain et al. [9] maintain that many rural poor in developing countries depend on rural farming as a crucial means of income and food security. In Africa, for example, about $70 \%$ of the population is involved in smallholding agriculture; and based on this, agriculture is said to remain Africa's surest way for growing inclusive economies and creating decent employment opportunities for her young people [10]. The relevance of smallholder agriculture for the growth and development of developing economies cannot thus be overemphasized. However, certain characteristics of these farmers and the areas they live make them susceptible to several global challenges such as soil degradation/erosion. In fact, farmers in underdeveloped areas are caught in a vicious cycle. The underdeveloped situations of these areas lead to more erosion/degradation, in addition, the economic impact of soil erosion increases in the areas.

The threats posed by soil erosion to the food security and survival of the human race makes it a main agricultural challenge globally. The annual loss of crop yield due to soil erosion in Africa today is estimated at 280 million tonnes [11]. Losses of soil organic carbon (SOC), nitrogen $(\mathrm{N})$, and phosphorus $(\mathrm{P})$ due to erosion and poor farm practices are estimated to the tune of 270 million tons annually in Africa [12]. In simpler terms, Gabathuler et al. [13] provide a clearer picture of this. It is said that, while the average global annual soil formation rate is $1 \mathrm{t} / \mathrm{ha}$ for example, average soil loss due to soil erosion is 75 billion tonnes globally, which is an overwhelming concern. Similarly, while the average soil loss due to soil erosion on cropland in Africa, South America and Asia is 30-40 t/ha; soil nutrient depletion of agricultural land in sub-Saharan Africa is $22 \mathrm{~kg} \mathrm{~N} / \mathrm{ha}, 2.5 \mathrm{~kg} \mathrm{P} / \mathrm{ha}$, and $15 \mathrm{~kg}$ $\mathrm{K} / \mathrm{ha}$ [13].

Rural farmers play significant roles in everyday decisions which, over time, determine the evolution of our landscape, including its degradation and sustainability [14]. Giving 
attention to their adoption behaviours is key to actualizing the sustainable ideals. While this is particularly very necessary, the daunting reality is that, if no strong sustainable agricultural measures are taken, within the next 50 years, due to the added problem of climate change impact, yields of food crops will decrease significantly. According to Sultan et al. [15], estimates indicate that mean yield reduction in Africa can be up to $-8 \%$, while that of West Africa can be up to $-11 \%$. Similarly, a $50 \%$ wheat production of over $70 \%$ population (about 1.1 billion) practicing agriculture in rural areas of South Asia is anticipated to decline by 2050, if no change of agricultural behaviours are adopted [16]. Thus, FAO [17] posits that, in order to meet SDGs, with regards to food security and address the current climate change problems, agriculture and food systems must adopt measures that boost productivity and resource efficiency.

Investing on, or the decision to adopt soil erosion control is a behavioural issue, which begins with farmers' perception. An understanding of farmers' behavioural tendencies is central to being able to enhance farmers' capacity to use sustainable agriculture measures [18]. Perception plays prominent roles in technology adoption processes [19], [20]. Farmers who have positive perception regarding a technology usually have higher probabilities of adoption or investing in the technology [21]. According to Ervin and Ervin [22] and Asafu-Adjaye [23], farmers who form a good perception of soil erosion in their farms are also those who eventually are motivated towards adopting measures to combat it. Against this backdrop therefore, this paper focuses on two objectives. Firstly, it seeks to investigate rural farmers' perception on impact of soil erosion in South Africa, using the case of Upper and Lower Areas of Didimana, Eastern Cape as a case study. Secondly, it seeks to assess rural farmers' use of soil erosion control methods recommended by agricultural extension officers in the study area.

\section{A. Problem Conceptualization for the Information Needs of} the Study

Problem conceptualization is based on the fact that "a problem well put, is a problem half solved" [24]. Problem conceptualization therefore is defined as a hypothetical construct which provides a scientific basis for a systematic analysis of causes of a problem [24]. It is very useful for agricultural studies because it enhances effective breakdown of problems into easily manageable bits [25]. As such, the model adopted for the information needs of this study is adapted from Duvel et al. [4] and Lategan [26]. According to the model (Table I), farmers' production/practice behaviour is influenced by their production environments (independent variables), which includes variables, such as farmers' personal/demographic, institutional and environmental factors. The influence of the independent factors is mediated through the more immanent factor, 'farmers' perception'. This thus produces the type of practice behaviours of farmers, ultimately translating into the type of soil erosion/degradation and/or yield capacity of farmland.

\section{Methodology}

\section{A. Description of Study Area}

This study was conducted at Upper and Lower Areas of Didimana, Eastern Cape, South Africa. The study area consists of Upper Didimana, Lower Didimana, and Romanslaagte villages. It is positioned on latitude $32^{\circ} 06^{I} 00^{I I} \mathrm{~S}$ and longitude $26^{\circ} 34^{I} 59^{I I}$ E. Located in Ward III of the Tsowana Local Municipality, Chris Hani District Municipality of the Eastern Cape, South Africa, the villages are roughly less than three kilometres apart. The socioeconomic constitution of the area consists of high levels of unemployment; 53\% poverty; and livestock production makes up a high percentage of income sources of people in the area [27]. The climatic and vegetation situation of the study area also varies from arid to very cold high veldt and falls majorly into two climate zones. These are the arid and semi-arid moderate midlands, and arid and semi-arid cold high lying land. In addition, mean annual precipitation of the area is between 301-600 mm, while average minimum and maximum temperatures in the area are $8.9^{\circ} \mathrm{C}$ and $22.3^{\circ} \mathrm{C}$, respectively.

\section{B. Data Collection and Analysis Process}

The cross-sectional research approach was adopted for the study. As such, data were collected at one setting from 60 smallholder farmers, through a random sampling process. Through the assistance of the extension officer, at the Department of Agriculture, Forestry and Fisheries (DAFF), Whittlesea (the department responsible for the Ward), data were collected one-on-one using semi-structured questionnaires. Basic information collected from farmers were on: their age as at the time of data collection; education status; gender; as well as their marital status. Others include their perception on soil erosion characteristics in their area, vis-àvis the severity of soil erosion impact in their area; soil erosion impact on their livelihoods; as well as changes in crop planting pattern due to soil erosion impact. The other aspects of information collected from farmers were information on farmers' use of agricultural extension officers' advises and/or recommendations. Data analysis was with SPSS package version 20, using basic analyses processes such as frequencies, percentages, mean and graph.

\section{RESUlTS AND DISCUSSION}

\section{A. Personal and Demographic Profile of Farmers in the Study Area}

According to the Table II, average farming age in the study area is 57 years, suggesting an ageing farming population, which is a common phenomenon in most developing countries today, especially in sub-Saharan Africa. The percentage of young (ages less than 35 years, which is the maximum age of youth in South Africa) farmers in the area is only $15 \%$. This problem is however common today due to the problem of high rural underdevelopment in many of those developing countries, and agriculture has not been projected as lucrative. 
As such, the rural areas have over the years seen a mass exodus of able-bodied youth to urban areas, and even overseas in search of so-called 'greener pastures'

TABLE I: PROBLEM CONCEPTUALIZATION FOR THE INFORMATION NEEDS OF THE STUDY

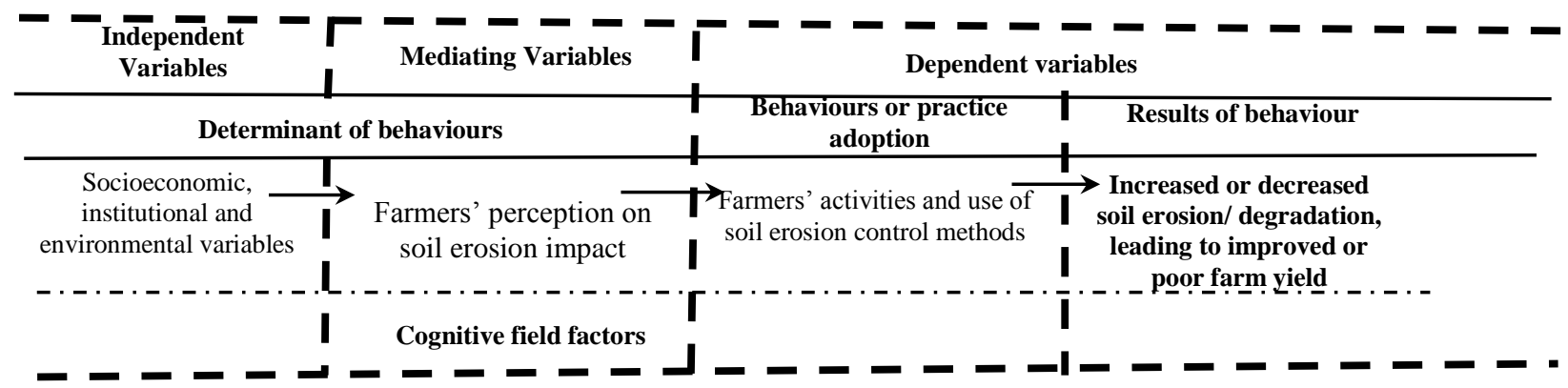

. Although age in technology adoption literatures is dual in nature and empirically ambiguous [28], [29], findings of this paper however is congruent with Agidew and Singh [30], who showed in their findings that older farmers have higher probabilities to adopt sustainable land management (SLM) technologies, thus experiencing improved productivity. Similarly, findings here agree with that of Biratu and Asmamaw [31], who also discovered that older farmers are more willing to participate in soil and water conservation (SWC) technologies introduced in their area.

TABLE II: PERSONAL AND DEMOGRAPHIC PROFILE OF FARMERS

\begin{tabular}{c|c|c}
\hline Age groups (years) & Percent & Average \\
\hline$<35$ & 15.0 & 57 years \\
$36-55$ & 33.3 & \\
$>56$ & 51.7 & \\
Gender of farmers & Percent & \\
\hline Male & 53.3 & \\
Female & 46.7 & \\
Marital status of farmers & Percent & \\
\hline Married & 60.0 & \\
Others & 40.0 & \\
Education levels of farmers (years) & Percent & \\
\hline No formal education & 1.7 & \\
Grade 1-12 & 91.7 & \\
Others & 6.7 & \\
\multicolumn{2}{c|}{ Source: Fieldwork 2012 }
\end{tabular}

The gender constitution of the study area is relatively biased, as there are more males (53\%) than females $(47 \%)$ in the area. This does not conform with the United Nations call for gender equality (SDG 5) [32]. Also, this finding seems different from literature evidence, which suggests that women contribute more to agriculture production in many developing areas, particularly in sub-Saharan Africa [33]. This finding however agrees with Maka et al. [34], suggesting that there is a link between gender and economic roles in the rural areas of the Eastern Cape, where men engage in farming activities, while women carry out petty trading. Similarly, a larger proportion $(60 \%)$ of farmers in the study area are married as opposed to the other marriage group, which may be considered as a positive factor for soil erosion control method use in the study area. Information on the role of marital status on technology adoption is scarce in the literature. However, Wood et al. [35] opine that an increasing body of literature seems to suggest that marriage as a variable may have a broad range of benefits, which include enhancement of individual's financial wellbeing, mental and physical health, as well as the wellbeing of their children, ultimately leading to improved and appropriate behavioural tendencies.

The education level of farmers in the study area may be said to be relatively poor, as only $7 \%$ of farmers exceeded Grade 12 level of education. With the agricultural intensification required to meet up with current global food systems and the ever growing world population, education level of farmers is indeed an immense asset in this equation. In view of this, Baiyegunhi et al. [36] found that farmers with higher education levels had a high probability to participate in the extension programmes implemented in KwaZulu-Natal Province, South Africa. Similarly, Osabohien et al. [7] also observed that education was significant in reducing poverty, particularly in rural areas, where agriculture is a main source of livelihood.

\section{B. Rural Farmers' Perception and Use of Erosion Control Methods}

Farmers' perception plays significant roles in their behaviour intent, which usually results to actual adoption of required technologies [37]. Duvel [24] argues that perception is one of the three mediating variables immanently responsible for farmers' behaviours. Ighodaro and Mushunje [21] however argue that due to the special role of perception, it should be regarded as foremost in the list of mediating variables, through which the impact of all other variables are transmitted, including that of the other members of the mediating variables. While the consideration of personal characteristics is important in a research, as have already been done, farmers' perception was also tested as it applies to the two main objectives of this paper, using three key variables in the study area. These includes: perception on soil erosion impact on farmer's sustainability; livelihoods; as well as on changes in crop planting due to soil erosion impact. Findings are as presented in the Table III.

According to the Table III, farmers' responses are presented thus: over half of farmers' population $(53.3 \%)$ indicated that soil erosion impact on their farming sustainability is severe. Amongst all farmers' livelihood factors, a larger percentage of farmers $(40 \%)$ said that soil erosion impacts negatively highest on their crops and livestock. In relation to how soil 
erosion impacts on their crop planting patterns, the largest percentage of farmers $(36.7 \%)$ suggested that due to the impact of soil erosion on their farms, they actually plant fewer crops every year. In other words, their productivity is gradually experiencing a downward trend due to soil erosion impact, which is actually one of the main consequences of unchecked erosion. In the light of this findings, two main observations can be made. Firstly, is that farmers in this study seem to possess a positive perception of the soil erosion impact in their area. According to Ighodaro and Muhunje [21], positive perception is important because it usually leads to adoption. Meseret [38] also argues that perception of soil degradation and its control measures is an important requirement for farmers' investment in control measures. In earlier studies by Ervin and Ervin [22] and Asafu-Adjaye [23], perception was as well found significant in farmers' investment in soil erosion/conservation measures. A second observation is that findings here indicate the downward trend associated with soil erosion impact when not controlled. Without appropriate adoption of soil conservation measures, agricultural production will persistently decline, which in turn will influence the food security of any particular nation [39].

TABLE III: FARMERS' PERCEPTION ON SOIL EROSION MMPACT

\begin{tabular}{c|c}
\hline Severity of erosion on sustainability & Percent \\
\hline Very severe & 28.0 \\
Severe & 25.0 \\
Moderately severe & 12.0 \\
A little severe & 22.0 \\
Not limiting at all & 13.0 \\
Soil erosion impact on livelihoods & Percent \\
\hline Household feeding & 15.0 \\
Impact on crops and livestock & 40.0 \\
Destruction of infrastructures/properties & 13.3 \\
No impact at all & 8.3 \\
Others & 23.3 \\
Change in crop planting due to soil erosion & Percent \\
\hline I'm actually planting less every year & 37.0 \\
Once in a year & 18.0 \\
Every two years & 17.0 \\
More than two years & 5.0 \\
Have never changed despite soil erosion & 23.0 \\
\hline
\end{tabular}
Source: Fieldwork 2012

The last variable to address in this paper is that which relates to how farmers use soil erosion control measures and/or recommendations by extension in the study area. The role of agricultural extension in the development of rural areas cannot be overemphasized. Advices and recommendations from extension therefore are crucial elements in this regard, and in-adherence surely will be very costly. Oladele and Tekena [40] maintain that agricultural extension is the most important avenue of information to farmers in most countries of Africa. According to OECD [41], agricultural technology adoption depends on a number of factors, including education, training, advice and information, which underlie the eventual knowledge capacities of farmers. This is why, agricultural extension is none-negotiable in agricultural development.

Based on findings (Table IV), a larger proportion of farmers (42\%) do not use extension advices at all, while $37 \%$ use them arbitrarily; only $21 \%$ can be said to use them as recommended.
As revealed, findings like these should be a cause to worry. According to Duvel [24], more often than not, problems usually addressed in agricultural development are ultimately that of non-adoption or inappropriate (arbitrary) adoption of certain recommended practices. Makate and Makate [42] however commented, that less effective extension services associated with less competent agricultural extension officials have been spotted to have less impact in compelling users to adopt. This finding is similar to that by Al-Zahrani et al. [43], who found that farmers had negative perceptions regarding agricultural extension services for realizing sustainable biological yields, in a study they conducted in Pakistan. Similarly, this study also is in consistent with the finding of Ighodaro and Mushunje [44], who found that smallholder farmers preferred their own practices instead of extension recommended practices on soil conservation in the Eastern Cape.

TABLE IV: FARMERS' USE OF EXTENSION ADVICES AND/OR RECOMMDED PRACTICES

\begin{tabular}{c|c|c}
\hline Use of extension advices & Frequency & Percent \\
\hline Not at all & 25 & 41.7 \\
Very limited & 10 & 16.7 \\
Sometimes & 12 & 20 \\
Quite often & 11 & 18.3 \\
Regularly & 2 & 3.3 \\
\hline \multicolumn{2}{|c|}{ Source: Fieldwork 2012 }
\end{tabular}

Source: Fieldwork 2012

\section{CONCLUSION AND RECOMMENDATIONS}

The decision to adopt or not adopt soil erosion control by farmers is a behavioural issue, which begins with perception. An understanding of farmers' behavioural tendencies therefore is considered central to being able to enhance their capacity to use sustainable agriculture measures such as soil erosion control methods. Farmers who have positive perception regarding a technology or an agricultural problem usually possess higher probabilities of investing in the technology that will address the problem. In this paper, though rural farmers in the study area possess a positive perception of the severity of soil erosion in their area, it is however very remarkable, that advices from agricultural extension officers are not taken seriously. They are either not adopted, or the few who use them, use them arbitrarily. As such, soil erosion activities keep increasing in the study area, as majority claim, apart from other impacts, they actually now experience a yearly deterioration in the pattern of their crop planting due to the continued increase of soil erosion impact. If this is allowed to continue, agriculture which has been noted a very crucial element for the development and survival of rural people is at great risk.

A concerted effort is therefore recommended from all to address this problem. Secondly, a national education campaign on soil erosion and its control for the rural people is therefore recommended, right from its early stages of development. One way this can be achieved is to incorporate soil erosion and its dynamics into the school curriculum, right from the lowest school grades. Also, the problem of infrastructural development which usually prevails in most of our rural 
communities should be addressed, since this is one of the main reasons for the mass exodus of able-bodied youth to cities in search for greener pastures. Similarly, the problem of inadequate education in our rural areas should as well be addressed. This is very important because, agricultural systems need to be improved to meet up with the fast moving technological advancement of the world, if it can be able to feed the ever growing global population. Finally, extension services need to improve, as the problem of extension ineffectiveness has been said to be responsible why many farmers in the rural areas prefer their own practices instead of extension advices and/or recommendations.

\section{REFERENCES}

[1] W. Adzawla, M. Sawaneh, and A.M. Yusuf, "Greenhouse gasses emission and economic growth nexus of sub-Saharan Africa," Scientific African, vol. 3, pp. 1-9, April 2019. https://doi.org/10.1016/j.sciaf.2019.e00065

[2] G.R. Aguilar, and A. Sumner, "Who are the world's poor? A new profile of global multidimensional poverty," World Development, vol. 126, pp. 1-15, November 2020. https://doi.org/10.1016/j.worlddev.2019.104716

[3] FAO. Smallholders and Family Farmers. 2012, p. 1. [Online]. Available:

http://www.fao.org/fileadmin/templates/nr/sustainability_pathways/docs /Factsheet_SMALLHOLDERS.pdf.

[4] G.H. Duvel, Y. Chiche, and G.J. Steyn, "Maize production efficiency in the Arsi Negele farming zone of Ethiopia: a gender perspective," $S$. Afr. J. Agric. Ext./S. Afr. Tydskr. Landbouvoorl., vol. 32, pp. 60-72, 2003.

[5] D. Masiwa. (July 2019). Small-scale farmer support programme gives rural farmers a second chance. [Online]. Available: https://www.foodformzansi.co.za/small-scale-farmer-supportprogramme-gives-rural-farmers-a-second-chance/.

[6] T.N. Linh, H.T. Long, L.V. Chi, L.t. Tam, and P. Lebailly, "Access to rural credit markets in developing countries, the case of Vietnam: a literature review," Sustainability, 11, pp. 1-18, March 2019. https://doi.org/10.3390/su11051468

[7] R. Osabohien, O. Matthew, O. Gershon, T. Ogunbiyi, and E. Nwosu, "Agriculture development, employment generation and poverty reduction in West Africa", The Open Agriculture Journal, vol. 13, no. 83, pp. 82-89, May 2019. https://doi.org/10.2174/1874331501913010082

[8] T.S. Jayne, et al., "Are medium-scale farms driving agricultural transformation in sub-Saharan Africa?", Agricultural Economics, vol. 50, pp. 75-95, October 2019

https://doi.org/10.1111/agec.12535

[9] I. Hossain, A.D. Muhammad, B.T. Jibril, and S. Kaitibie, "Support for smallholder farmers through Islamic instruments: the case of Bangladesh and lessons for Nigeria", International Journal of Islamic and Middle Eastern Finance and Management, vol. 12, no. 2, pp. 154-168, February, 2019. https://doi.org/10.1108/IMEFM-11-2018-0371

[10] AGRA, Africa Agriculture Status Report: The Business of Smallholder Agriculture in Sub-Saharan Africa, Issue 5. Nairobi, Kenya: Alliance for a Green Revolution in Africa (AGRA), 2017, p. vi.

[11] M. Sartori, et al., "A linkage between the biophysical and the economic: assessing the global market impacts of soil erosion", Land Use Policy, vol. 86, pp. 299-312, May 2019. https://doi.org/10.1016/j.landusepol.2019.05.014

[12] C.K.K. Gachene, S.O. Nyawade, and N.N. Karanja, "Soil and Water Conservation," in Zero Hunger, W. Leal Filho, A. Azul, L. Brandli, P. Ozuyar, T. Wall, Eds. Switzerland: Springer Nature, 2019, pp. 1-15. https://doi.org/10.1007/978-3-319-69626-3_91-1

[13] E. Gabathuler, H. Liniger, C. Hauert, and M. Giger, Benefits of Sustainable Land Management, Berne, Switzerland: World Overview of Conservation Approach and Technologies (WOCAT), Centre for
Development and Environment (CDE). 2009, pp. 1-15. [Online]. https://catalogue.unced.int/838_Benefits_of_SLM_eng.pdf.

[14] European Commission, Joint Research Centre (April 2019). Smallholder agriculture. [Online]. Available: https://wad.jrc.ec.europa.eu/smallholderagriculture.

[15] B. Sultan, D. Defrance, and T. Iizumi, "Evidence of crop production losses in West Africa due to historical global warming in two crop models," Scientific Reports, vol. 9, p. 12834, September 2019. https://doi.org/10.1038/s41598-019-49167-0

[16] S. Ali, et al., "Climate change and its impact on the yield of major food crops: evidence from Pakistan," Foods, vol. 6, No 39, pp. 1-19, May 2017. https://doi.org/10.3390/foods6060039

[17] FAO, Climate-smart Agriculture Case Studies 2018: Successful Approaches from Different Regiions, Rome: Food and Agriculture Organization of the United Nations, 2018, p. 3.

[18] G. Feola, A.M. Lerner, M. Jain, M. J.F. Montefrio, and K.A. Nicholas, "Researching farmer behaviour in climate change adaptation and sustainable agriculture: lessons learned from five case studies," Journal of Rural Studies, vol. 39, pp. 74-84, March 2015. https://doi.org/10.1016/j.jrurstud.2015.03.009

[19] M.D. Alemu, A. Kebede, and A. Moges, "Farmers' perception of soil erosion and adoption of soil conservation technologies at Geshy subcatchment, Gojeb river catchment, Ethiopia," Agricultural Sciences, vol. 10, pp. 46-65, January 2019. https://doi.org/10.4236/as.2019.101005

[20] C. Bopp, A. Engler, P.M. Poortvliet, and R. Jara-Rojas, "The role of farmers' intrinsic motivation in the effectiveness of policy incentives to promote sustainable agricultural practices," Journal of Environmental Management, 244, pp. 320-327, May 2019. https://doi.org/10.1016/j.jenvman.2019.04.107

[21] I.D. Ighodaro, and A. Mushunje, "Factors affecting smallholder farmers' perception regarding their use of soil conservation practices: evidence from farming at Qamata Irrigation Scheme, South Africa," J. Hum Ecol, 59, No 2-3, pp. 82-91, October 2017. https://doi.org/10.1080/09709274.2017.1353581

[22] C.A. Ervin, and D.E. Ervin, "Factors affecting the use of soil conservation practices: hypotheses, evidence, and policy implications," Land Economics, vol. 58, No 3, pp. 277-292, August 1982. https://doi.org/10.2307/3145937

[23] J. Asafu-Adjaye, "Factors affecting the adoption of soil conservation measures: a case study of Fijian cane farmers," Journal of Agricultural and Resource Economics, vol. 33, No 1, pp. 99-117, April 2008.

[24] G.H. Duvel, "Towards a model for the promotion of complex innovations through programmed extension," S. Afr. J. Agric. Ext./ S. Afri. Tydskr. Landbouvoorl., vol. 20, pp. 70-86, 1991.

[25] I.D. Ighodaro, F.S. Lategan, and S.F.G. Yusuf, "The impact of soil erosion on agricultural potential and performance of Sheshegu community farmers in the Eastern Cape of South Africa," Journal of Agricultural Science, vol. 5, No 5, pp. 140-147, April 2013. https://doi.org/10.5539/jas.v5n5p140

[26] F.S. Lategan, "The perceived impact of herd management practices on sustainable springbuck (antidorcas marsuplalis) ranching in the Eastern Cape Province of South Africa," S. Afr. Tydskr. Landbouvoorl./S. Afr. J. Agric. Ext., vol. 39, No 2, pp. 15-29, 2011.

[27] Chris Hani District Municipality, Chris Hani District Municipality: Five Year Integrated Development Plan Final Draft Report 2012-2017 (Unpublished), Queenstown, South Africa: Chris Hani District Municipality. 2012-2017, pp. 13-111.

[28] I.D. Ighodaro, F.S. Lategan, and W. Mupindu, "The impact of soil erosion as a food security and rural livelihoods risk in South Africa," Journal of Agricultural Science, vol. 8, no. 8, pp. 1-12, July 2016. https://doi.org/10.5539/jas.v8n8p1

[29] P. Brown, A. Daigneault, and J. Dawson, "Age, values, farming objectives, past management decisions, and future intentions in New Zealand agriculture," Journal of Environmental Management, vol. 231, pp. 110-120, October 2019. https://doi.org/10.1016/j.jenvman.2018.10.018

[30] A.A. Agidew, and K.N. Singh, "Factors affecting the adoption of sustainable land management practices at farm level in the Northeastern 
highlands of Ethiopia: the Televaven sub-watershed case study," $J$ Environ Pollut Manag, vol. 2, No 1, pp. 1-12, April 2019. https://doi.org/10.1186/s13717-018-0128-6

[31] A.A. Biratu, and D.K. Asmamaw, "Farmers' perception of soil erosion and participation in soil and water conservation activities in the Gusha Temela watershed, Arsi, Ethiopia," International Journal of River Basin Management, vol. 14, no. 3, pp. 329-336, April 2016. https://doi.org/10.1080/15715124.2016.1167063

[32] United Nations Development Programme (UNDP). (August 2020). Sustainable development goals. [Online]. Available: https://www.undp.org/content/undp/en/home/sustainable-developmentgoals.html (06/08/2020).

[33] T. Paris, and M.F. Rola-Rubzen, Gender Dimension of Climate Change Research in Agriculture (Case Studies in Southeast Asia), Wageningen, The Nederlands: CGIAR Research Program on Climate Change, Agriculture and Food Security (CCAFS), 2018, ch. 1, p. 2

[34] L. Maka, I.D Ighodaro, and G.P.T. Ngcobo-Ngotho, "Capacity development for scaling up climate-smart agriculture (CSA) innovations: agricultural extension's role in mitigating climate change effects in Gqumashe community, Eastern Cape, South Africa," S. Afr. J. Agric. Ext., vol. 47, no. 1, pp. 45-53, i8/ccxApril 2019. https://doi.org/10.17159/2413-3221/2019/v47n1a488

[35] R.G. Wood, B. Goesling, and S. Avellar, The Effects of Marriage on Health: A Synthesis of Recent Research Evidence, An ASPE Research Brief Prepared for the U.S. Department of Health and Human Services Office of the Assistant Secretary for Planning and Evaluation, Office of Human Services Policy, No 9, 2007, ch. 1, p. 1. [Online]. Available: https://aspe.hhs.gov/system/files/pdf/75106/report.pdf.

[36] L.J.S. Baiyegunhi, Z.P. Majokweni, and S.R.D. Ferrer, "Impact of outsourced agricultural extension programme on smallholder farmers' net farm income in Msinga, KwaZulu-Natal, South Africa," Technology in Society, vol. 57, pp. 1-7, November 2019. https://doi.org/10.1016/j.techsoc.2018.11.003

[37] R.B. Tranter, J.R. Park, and P.T. Dorward, "Identifying and understanding factors influencing the uptake of new technologies on dairy farms in SW England using the theory of reasoned action," Agricultural Systems, 94, pp. 281-293, September 2007. https://doi.org/10.1016/j.agsy.2006.09.006

[38] D. Meseret, "Determinants of farmers' perception of soil and water conservation practices on cultivated land in Ankesha District, Ethiopia," Agricultural Science, Engineering and Technology Research, vol. 2, no. 5, pp. 1-9, November 2014.

[39] M. Barungi, and B.B. Maonga, "Adoption of soil management technologies by smallholder farmers in central and southern Malawi," Journal of Sustainable Development in Africa, vol. 13, no. 3, pp. 28-38, January 2011.

[40] O.I. Oladele, and S.S. Tekena, "Factors influencing agricultural extension officers' knowledge on practice and marketing of organic agriculture in North West Province, South Africa," Life Science Journal, vol. 7, no. 3, pp. 91-98, September 2010.

[41] OECD, Adoption of Technologies for Sustainable Farming Systems: Wageningen Workshop Proceedings, Paris, France: Organization for Economic Co-orperation and Development, 2001, p. 6. [Online]. Available: $\quad$ https://www.oecd.org/greengrowth/sustainableagriculture/2739771.pdf

[42] C. Makate, and M. Makate, "Interceding role of institutional extension services on the livelihood impacts of drought tolerant maize technology adoption in Zimbabwe," Technology in Society, vol. 56, pp. 126-133, September 2019. https://doi.org/10.1016/j.techsoc.2018.09.011

[43] K.H. Al-Zahrani, A.Q. Khan, M.B. Baig, M. Mubushar, and A.H. Herab, "Perception of wheat farmers toward agricultural extension services for realizing sustainable biological yields," Saudi Journal of Biological Sciences, vol. 26, pp. 1503-1508, February 2019. https://doi.org/10.1016/j.sjbs.2019.02.002

[44] I.D. Ighodaro, A. Mushunje, B.F. Lewu, and B.E. Omoruyi, "Climatesmart agriculture and smallholder farmers' income: the case of soil conservation practice-adoption at Qamata Irrigation Scheme, South Africa,"J Hum Ecol, 69, no. 1-3, pp. 81-94, January 2020. https://doi.org/10.31901/24566608.2020/69.1-3.3207

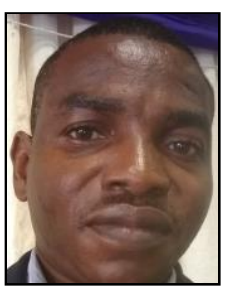

Ighodaro Ikponmwosa David is a $\mathrm{PhD}$ degree holder in Agriculture, majoring in Agricultural Extension and Rural Development, from the University of Fort Hare (UFH), South Africa in 2016. He is also B.Sc. (Honors) degree holder in Geography and Regional Planning, from the University of Benin, Nigeria, as well as a Postgraduate Diploma degree holder in Higher Education and Training (UFH).

$\mathrm{He}$ is a researcher and lecturer. He has served at various lecturing and research positions between 2010 and 2020, at the University of Fort Hare, Mangosuthu University of Technology, Durban, and the Cape Peninsula University of Technology, Cape Town, all in South Africa. He is currently employed as a Postdoctoral Research Fellow at the Cape Peninsular University of Technology, Cape Town.

Dr Ighodaro's broad research focus is on the sustainability of agricultural soils. His specific research focuses are: soil conservation, climate-smart agriculture (CSA), soil erosion impact on agriculture, farmers' adoption decision-making, agricultural extension and rural development. 